\title{
The Profile of Non-native Teacher's Oral Skills: A Study Carried Out in Brasília, the Capital of Brazil
}

\author{
Joana Grant ${ }^{\mathrm{i}}$ \\ English Language Teaching Department, Cooplem Idiomas ${ }^{\text {ii }}$, Brazil
}

Copyright $\mathrm{C} 2017$ by authors, all rights reserved. Authors agree that this article remains permanently open access under the terms of the Creative Commons Attribution License 4.0 International License

\begin{abstract}
Thorough academic studies and pressing needs to meet professional demands in Brazil were the driving force guiding this work, which catered to map out non-native English teachers regarding to their oral skills. The research, within the context studied, identified the profile of practitioner's (oral skills) teaching primary and secondary levels, within the public and private sectors and an educational cooperative language school, Cooplem Idiomas, in the capital of Brazil. We aimed to find out whether or not the target language (English) circulated in the classrooms observed between 2014 and 2016, and analyzed how the recruitment and selection process worked to identify the teaching oral skills of the non-native English language teachers. The results of the observations pointed out that the same teacher taught in the target language in one educational sector, but taught the target language in the mother tongue (Portuguese) in another sector. It was, also, identified that teaching target language in the mother tongue can be a result of poor oral language skills, lack of awareness to teach English in English and specific school policies. Therefore, we concluded that we would like to see the Brazilian government bringing more investment into education, and assess teachers oral skills before entering into teaching, so proper and effective funding can foster better results for the nation, concerning to language teaching.
\end{abstract}

Keywords Oral Skills, Non-native Language Teachers, Grammar and Communicative Approaches, Target Language, Insufficient (or Low) Oral Skills, Limitrophe ${ }^{1}$ Oral Skills, Sufficient Oral Skills

\section{Introduction ${ }^{2}$}

The issues relating to non-native oral skills teaching

\footnotetext{
${ }^{1}$ We bring a definition for Limitrophe oral skills representing teachers who have some oral proficiency, but the level is not suitable to teach a foreign language to a standard that can help students to acquire the language studied.

2 This paper is an extract from our dissertation ${ }^{2}$ presented as criteria to obtain Master degree in Applied Linguistics at Universidade of Brasilia $(U n B)$, on $4^{\text {th }}$ March 2016.
}

abilities, here presented, within the classroom and the key facts outlining the study are on the basis of input hypothesis suggested by Krashen,[1], grammatical and communicative approach suggested by Almeida Filho, [2], lack of proper educational policies in Brazil suggested by

Mastrella-de-Andrade, [3], and the fact that non-native teachers from a more academic, knowledge-based tradition dominate language education in Brazil suggested by Consolo, [4]. Classroom observation was the basis of the investigation - alongside questionnaires posted on the University Facebook and sent via e-mails, interviews and pedagogical meetings - to find out why teachers teach how they teach and why students learn how they learn, Almeida Filho, [2]. The evidence gathered aided to profile the investigated teachers whilst they conducted their English classes in the public Local Government Authority (LEA) in Distrito Federal (DF), private sectors and in the foreign language school, all in Brasilia, the capital of Brazil. The three profiles identified in the study is presented on section 2.4 , (table 2, pg. 8)

\section{Materials and Methods}

We have chosen the qualitative research to identify investigated English language teachers' profile and their oral skills within the context presented, via case study as

Unlike most ethnography, case studies focus on one particular instance of educational experience and attempt to gain theoretical and professional insights from a full documentation of that instance.

Researchers in a variety of professional and practical domains use case studies as a way of conducting and disseminating research to impact upon practice, and to refine the ways in which practice is theorized, Freebody, [5].

Therefore, the tools used in the study are known as "strong data" Moura Filho, [6] having in mind to bring precision in order to know the relationship between non-native English oral skills, their teaching approaches and government 
policies. The work was planned and divided into five parts. $1^{\text {st }}$ Sending the pilot questionnaire to 125 English teachers, via e-mail; $2^{\text {nd }}$ Handing a further questionnaire to 60 teachers whilst they were participating in the yearly pedagogical meeting at Cooplem Idiomas, they were part of the same group of teachers who received the pilot questionnaire via e-mail; $3^{\text {rd }}$ Posting the questionnaire on-line via our personal page on Facebook, using Survey Monkey application; $4^{\text {th }}$ English classes observations within LEA and the private sector, and $5^{\text {th }}$ interviews and messages exchange with the subjects participating in the research. Finally, to maintain the confidentiality and ethic in the study all participants were allocated a code, $\mathrm{R}=$ respondent, $1=$ refers to the fluency ranking profile, or the participation order in the research, followed by the initials of his/her name, e.g. (R1EP).

\subsection{Native English Language Teaching Approximate Population}

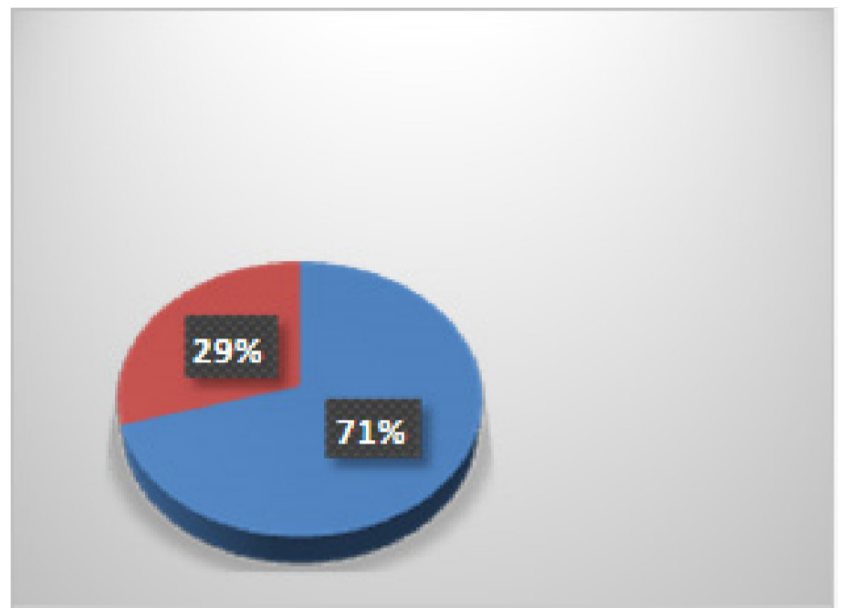

Figure 1. Teachers registered with federal government education. Source: Ministry of Education and Culture(MEC)/ National Institute of Educational Studies and Research Anísio Teixeira (INEP) (2015)

In order to gather evidence to register the teaching and learning patterns from the studied sample, and the observed classrooms we relied on the need to employ quantitative resources, although we have selected the qualitative tools in the study, as both can be used to measure the observations and establish the facts to explain to the academic community, Chizzotti, [7], Laville et al., [8], how and why teachers use the mother tongue to teach a target-language, in this case, English language. Figure 1 reflects a fraction of non-native English practitioners in Brazil according to the Ministry of Education and Culture (MEC). The focus of the study is the practitioners' fluency in the Brazilian capital, teaching to elementary to secondary level (teachers' first language is Portuguese), and it was considered important to present the number of practitioners registered by the federal government, as employed teachers in Brasília may come from any part of Brazil to take up the teaching position, via the national recruitment process.

\subsection{Approximate Non-native Brazilian Teacher Population}

Recently, a pedagogical mapping relating to the number of graduated teachers was carried out by the British Council, based on 2013 data, published in 2015, our research accounts for 144,848 non-native Brazilian teaching population based on 2014 data provided by the federal government. The data on figure 1, pg. 3 indicates that $71 \%$ (102.156) professionals teach elementary level and 29\% $(42,692)$ teaching secondary level, approximately. This study - in particular - brings a fraction of teachers in DF, the link between the federal (figure 1, pg. 3) and local data (figure 2, pg. 4), is that teachers' knowledge are not cognitive contents defined at once, but built up along life experience (and in any county), and the researched teachers come from all parts of Brazil, furthermore it has the capacity to transform situations into action, Gimmenez, [9]. Converging with the author, we sign the notion that non-native language teachers are not the holders of knowledge and contents only, they need to be fluent in the language they teach or wish to teach, based on knowledge that can be implicit or tacit, beyond the conscience of writing skills. Thus, teachers need to have sufficient oral skills (be fluent) and use the target language in their classrooms under real and certain conditions as suggested by Almeida Filho [2].

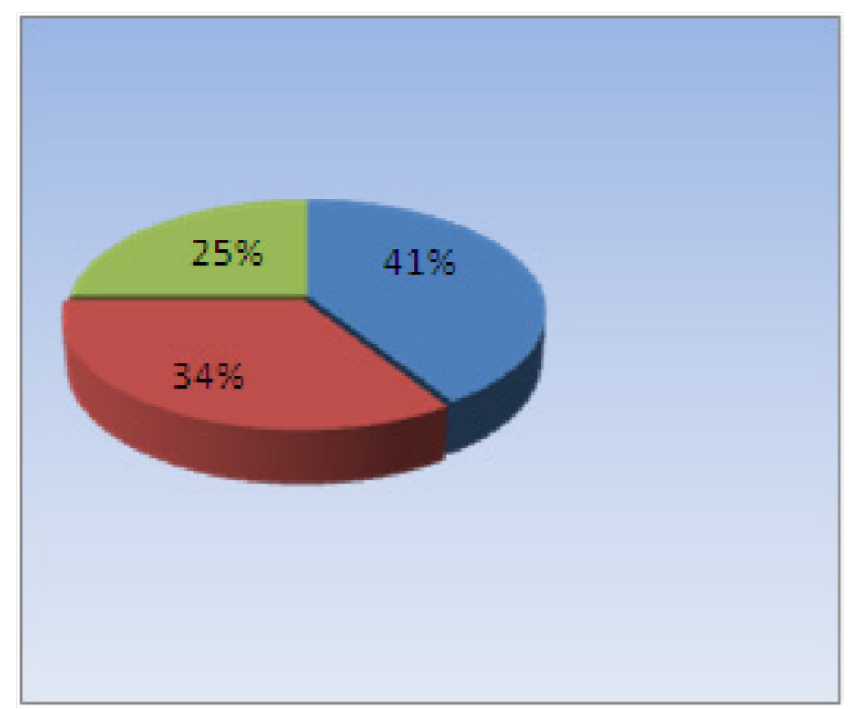

Source: LEA-GDF, (2015)

Figure 2. English language teacher LEA-GDF public sector. Total $=771$

According to official data supplied by the LEA, on around $20^{\text {th }}$ February 2015, 219 English teachers were available to attend the schools, but the government could not precise how many teachers were needed to attend the academic demand. This fact alone called our attention as the Brazilian capital county was only two weeks away from the beginning of the term, and so far, the local government did not have sufficient professionals employed to teach in its schools. A further information, from the government, after the beginning of the term, as shown in (figure 2. pg. 4) indicates that 771 professionals were teaching across the county, a total of $41 \%$ 
(316) teachers were employed to teach for elementary level, $34 \%$ (262) for secondary level, and $25 \%(193)$ at the Interschool Language Centers (CILs) ${ }^{3}$.

According to the government, there are contractual obligations to follow administrative and legislative proceedings, (cf. Fiscal Responsibility Law, National Curricular Parameters $(\mathrm{PCN}){ }^{4}, 1997: 25$, and Directives Bases of National Education Law (LDB). ${ }^{5}$ We acknowledge that those conditions have to be taken into consideration, and found that students were not being able to attend the English classes because teachers were not appointed in time to be in the classroom, verifying also that this is a common occurrence within the Brazilian public sector, one of the subjects of this study said:

When I started teaching at the school, it came to my attention that although English language is obligatory in the public schools as from the 5th year grade, Elementary Level II (EFII), many students had no access to English classes, from one year and a half, due to lack of teachers in the school, and they were infinitely de-motivated. (RL1)

There are specific Brazilian laws stating foreign language teaching constitutional rights, but in some parts of Brasilia, students do not have access to the English classes due to lack of teachers employed by the government. This situation therefore, suggests that (within the sample researched) the LEA do need to look more closely into the language teaching demands in some of the capital constituencies.

\subsection{Recruitment and Selection Process within the Local Education Authority}

To discuss non-native English language teachers' recruitment and selection, three public advertisements were analyzed, known in Brazil as "concurso público", (CP). The first Public Advertisement $n^{\circ}$ 01-SEAP/SEE, 04/09/2013, carried out by the Instituto Brasileiro de Formação e Capacitação (IBFC), 2nd, Public Advertisement $\mathrm{n}^{\circ}$ 1/2014-SEAP/SEEDF, 13/05/2014, carried out by Instituto Americano de Desenvolvimento (IADES), bringing the same examination type, written tests, teaching experience and/or qualification, not contemplating demand for oral test. The Public Advertisement $n^{\circ} 01 / 2010,2 \mathrm{nd} / 06 / 2010$, carried out by Fundação Universa, caters for three demands, written, oral test experience and/or qualification. In this context, until

\footnotetext{
3 The first Intereschool Language Centers was created in 1975 and its mission is to teach modern languages to students from the mainstream public schools. At present there are circa of 10 centers across the county teaching English, French, German, Spanish and Japanese, this year the CILs started to accept mature students from local communities.

${ }^{4}$ PCN or Parâmetros Curriculares Nacionais, are the national reference quality to guide the execution of educational plans within governmental public schools, introduced in Brazil in 1996. Link access: educarparacrescer.abril.com.br/indicadores/materias 295305.shtml 5 LDB or Lei de Diretrizes e Bases is the genera education Brazilian law and sets out the educational system, it was first approved by the National Congress in 1961 and implemented in 1971 and in 1996. Link access: educarparacrescer.abril.com.br/politica-publica/lei-diretrizes-bases-349321 .shtml
}

2010, the local government was demanding oral tests when recruiting and selecting language teachers, but from this date forward, no oral tests were included on its advertisements. That is an area of major concern, as there is pressing demand to improve foreign language teaching quality in the public sector, in particular. Therefore, as the CP in 2014 did not bring demand for the oral test, it is relevant to highlight to the local authorities the importance of oral examination, as made in 2010 to avoid recruiting language teachers that may not have the compatible oral skills to bring to the classroom, Teixeira da Silva, [12].

The fact that oral skills is one of the essential abilities to foster quality language teaching, non-native language teachers need to possess sufficient oral fluency, as described on (table 2, pg. 8), to teach in the public sector, and it is advisable that certification should be sought, for instance, by Examination Proficiency for English Language Teachers (EPPLE) ${ }^{5}$, Consolo, [13], an examination prepared specifically to assess Brazilian teachers oral English skills.

\subsection{Recruitment and Selection Process at Cooplem Idiomas}

Cooplem Idiomas caters primarily for the first agents, students, (definition given by Almeida Filho). In the school, the first agents hold a view that learning language means they have to learn grammar, the study gave the opportunity to evidence this belief on a daily-basis in the school as a practitioner and whilst conducting the research, which we seek to explain why teachers teach as they teach, Almeida Filho, [14]. One of the events in Cooplem's classroom, regarding to the approach demanded by the students, was one of many documents, this particular, signed by an advanced class with approximately 12 students, asking the Principal to "change the teacher as she wasn't teaching enough grammar".

Whilst the government is not demanding oral exams - to certify language teachers have sufficient oral skills before entering its mainstream English classes - Cooplem Idiomas certifies this ability at the beginning of its recruitment process - according to Professor Eduardo Brasil, president of the selection board. The selection is made every six months, the candidates do an English written test with 100 questions about teaching methodology, teaching approaches and vocabulary in order to go to the second stage of the selection, then candidates are tested about their oral skills by a 20 minutes class demonstration, in the target language. If candidates do not show that he/she can teach in the target language, they are eliminated from the process. Professor Brasil says that "the good candidate to work at Cooplem Idioma has to speak, read and write about teaching approaches in English".

The student learning culture preference for the grammatical approach it is part of the every-day classroom in the language school. We would say that the same also

\footnotetext{
${ }^{5}$ Access to EPPLE examination is: http://epplebrasil.org/
} 
happens in other educational settings in Brazil, even though the communicative classroom is being studied for at least four decades, Consolo, [10]. Maybe this fact is due to the communicative competency studies be rare in Brazil, see Almeida Filho, [15]. The students believe (as mentioned above) that the grammatical approach it is what is going to bring growth to their studies. This fact takes us to subscribe to academic postulations that teacher's oral fluency is more important, as it is the communicative competency crucial to language teaching in the event of real communication, Canale et al.,[13], not the grammatical approach. Highlighting, therefore, that we follow the view that both the grammatical and the communicative approaches, defined by Almeida Filho, [14], are crucial to successful language pedagogy.

\subsection{Class Observation Extracts to Draw Teacher's Profiling}

During the class observations, we registered how the English classes were conducted, posing particular interest whether non-native teachers were teaching in the mother tongue (Portuguese, in this context) or in the target language, (English).

Table 1. English classroom in Portuguese suggested instructions in the target language

\begin{tabular}{|c|c|}
\hline $\begin{array}{l}\text { Portuguese usage in the English } \\
\text { classroom (teacher and pupils) }\end{array}$ & $\begin{array}{c}\text { Suggested target-language } \\
\text { interference } \\
\end{array}$ \\
\hline $\begin{array}{c}\text { Aluno: Porquê a Sra. Não ensina o } \\
\text { alfabeto (em inglês)? Porque } \\
\text { ensina só os números? }\end{array}$ & $\begin{array}{l}\text { You meant: Why don't I teach you } \\
\text { the alphabet? Why do I teach only } \\
\text { the numbers? }\end{array}$ \\
\hline $\begin{array}{l}\text { Regente: Preste atenção que as } \\
\text { provas já estão sendo preparadas. }\end{array}$ & $\begin{array}{l}\text { Pay attention the exams are } \\
\text { coming soon. }\end{array}$ \\
\hline Regente: Me dê um nome. & Give-me a name, please. \\
\hline $\begin{array}{l}\text { Regente: Vamos lá gente o } \\
\text { horário está acabando }\end{array}$ & Let's go, time is almost up \\
\hline Aluno: Tá calor & Yes, it is hot \\
\hline Aluno: Não & No? \\
\hline Regente: Posso apagar o quadro? & Can I erase the board? \\
\hline $\begin{array}{c}\text { Regente: Me diz, fica } \\
\text { conversando, chegar em casa } \\
\text { treinar }\end{array}$ & $\begin{array}{c}\text { Tell me, please ... if you keep } \\
\text { talking ... when you get home you } \\
\text { need to study }\end{array}$ \\
\hline $\begin{array}{l}\text { Regente: Na prova não pode } \\
\text { esquecer isto }\end{array}$ & $\begin{array}{c}\text { You can't forget it, when you are } \\
\text { doing your exams }\end{array}$ \\
\hline Aluno: É um desafio. & Yes, it is a challenge \\
\hline Regente: Júlia, soletre o seu nome & Júlia, can you spell your name? \\
\hline $\begin{array}{l}\text { Regente: Você entendeu todas as } \\
\text { partes como se monta ...? }\end{array}$ & Do you understand how to do it? \\
\hline
\end{tabular}

Source: Grant, J. [16] (2016. pg. 74).
Table 2. Oral fluency Profile and definitions

\begin{tabular}{|c|l|}
\hline Profile & \multicolumn{1}{|c|}{ Teaching Definition/Characteristics } \\
\hline Insufficient & $\begin{array}{l}\text { a. Rarely uses the target-language; b: Use of } \\
\text { one or other word in English, sporadically; c: } \\
\text { Limits himself/herself to the reproduction of } \\
\text { grammatical rules on the board; and d: Prefers } \\
\text { to explain grammatical rules in Portuguese, } \\
\text { instead of using the target language (English). }\end{array}$ \\
\hline \multirow{5}{*}{ Limitrophe } & $\begin{array}{l}\text { a: Sporadically uses the target-language to } \\
\text { specific tasks (such as calling the nominal } \\
\text { register, pronunciation of some words on the } \\
\text { board, greetings, eventual reading and/or } \\
\text { dialogue); b: Teaches and sings songs with } \\
\text { the students using the target language. }\end{array}$ \\
\hline Sufficient & $\begin{array}{l}\text { a: Can teach any part of the syllabus in the } \\
\text { target-language; b: Teaches without much } \\
\text { difficulty, using the target-language almost of } \\
\text { the time; c: Gives instructions, correct and } \\
\text { motivates the students using the } \\
\text { target-language; d: Reads texts, asks questions } \\
\text { about of what was taught in the target } \\
\text { language. }\end{array}$ \\
\hline
\end{tabular}

Source: Grant, J. (2016. pg. 104).

The extract on (table 1, pg. 7) reflects teacher's speech, at the left side of the table in Portuguese, indicating passages of everyday instruction in the classroom that could well be given in the target language, not in Portuguese. It is also illustrating teacher's preference for using the mother tongue in the classroom, instead of the target language. At the right side of the table, we can find corresponding suggestions in English based on the understanding that if those instructions are given in the target language, teachers create better opportunities to good language input, therefore students can benefit from (i+1) suggested by Krashen, and have better opportunity to learn and acquire the language studied.

There have been a large number of complaints, mainly in the public sector, as a great number of English language professionals teach the target language (English) in Portuguese, but those complaints were not observed in the Cooperative. Students claim that the poor language fluency drives teachers to adopt the grammatical approach, leaving aside development of oral activities, said Teixeira da Silva, [11], this reality was observed in the private and in the public sectors, but not in Cooplem Idiomas (the Cooperative). Thus, the self-explanatory (table 2, pg. 8), drawn from the class observations, between November 2014 and February 2016, aided to draw and to define the three profiles observed. The use of Portuguese in the classroom, instead of English, was identified by this study and shown on table number 1 , above. 
The three profiles were drawn based on how each teacher delivered their classes. For instance, low oral skills evidenced that all classroom instructions and grammar rules were in Portuguese; limitrophe oral skills showed that the practitioner used the target language in some occasions, for instance teaching and singing a song in the target language, but did not use the full classroom time to provide significant amount of English input. The sufficient oral skills type evidenced that the teachers were fluent in English to teach in English in a more natural way, could present written text, read, ask and answer questions in English, providing significant input to students. It was, also, detected that in some instances, fluent teachers also taught the target language in Portuguese for other reasons, rather than lack of linguistic proficiency.

The outcome of the observations showed that linguistically fluent practitioners performed differently, bringing evidence that non-native teachers play a distinct role and have different levels of linguistic proficiency, claimed by Consolo [14]. This is to say that they would teach English in English in one school setting, but would teach English in the mother tongue (Portuguese) in another setting, although fluent in the target language. Therefore, the finding addresses the view that not only lack of fluency is an obstacle to teach target language in the target language, but teachers lack of awareness to teach in the target language. From the evidenced practices of non-native teaching process conducted in the mother tongue (Portuguese), table 2 below presents the profiling of the teachers observed, the categories for each profile identified and their oral skills qualified as follows: 1. Insufficient (or low) oral skills; 2. Limitrophe oral skills and. 3. Sufficient oral skills.

The representations from (picture 3) are part of some written samples from classes observed in the private (A) and in the public sector (B). The two teachers observed were ranked within the sufficient oral fluency type, (see table 2, pg. 8 ), are represented by the numbers ( 3 and 4 ), they are practitioners in the public and private sectors, concomitantly, and despite their fluency they both performed at different levels, as claimed by Consolo, [14]. In this study means that in the public sector they teach English in the mother tongue, Portuguese, and in Cooplem, English is taught in English. The teaching performance in the private school was also English taught in Portuguese, not because the teacher was not fluent, but because the teaching purpose is to teach students to be successful at National Secondary Education Examination (ENEM) ${ }^{6}$, and Grade Assessment Program or (Programa de Avaliação Seriada - PAS) ${ }^{7}$, thus the grammatical approach. This is another evidence that fluent English teachers are teaching the target language in the mother tongue, not because of lack of fluency in the language, but because the teacher needs to comply with school contractual obligations.
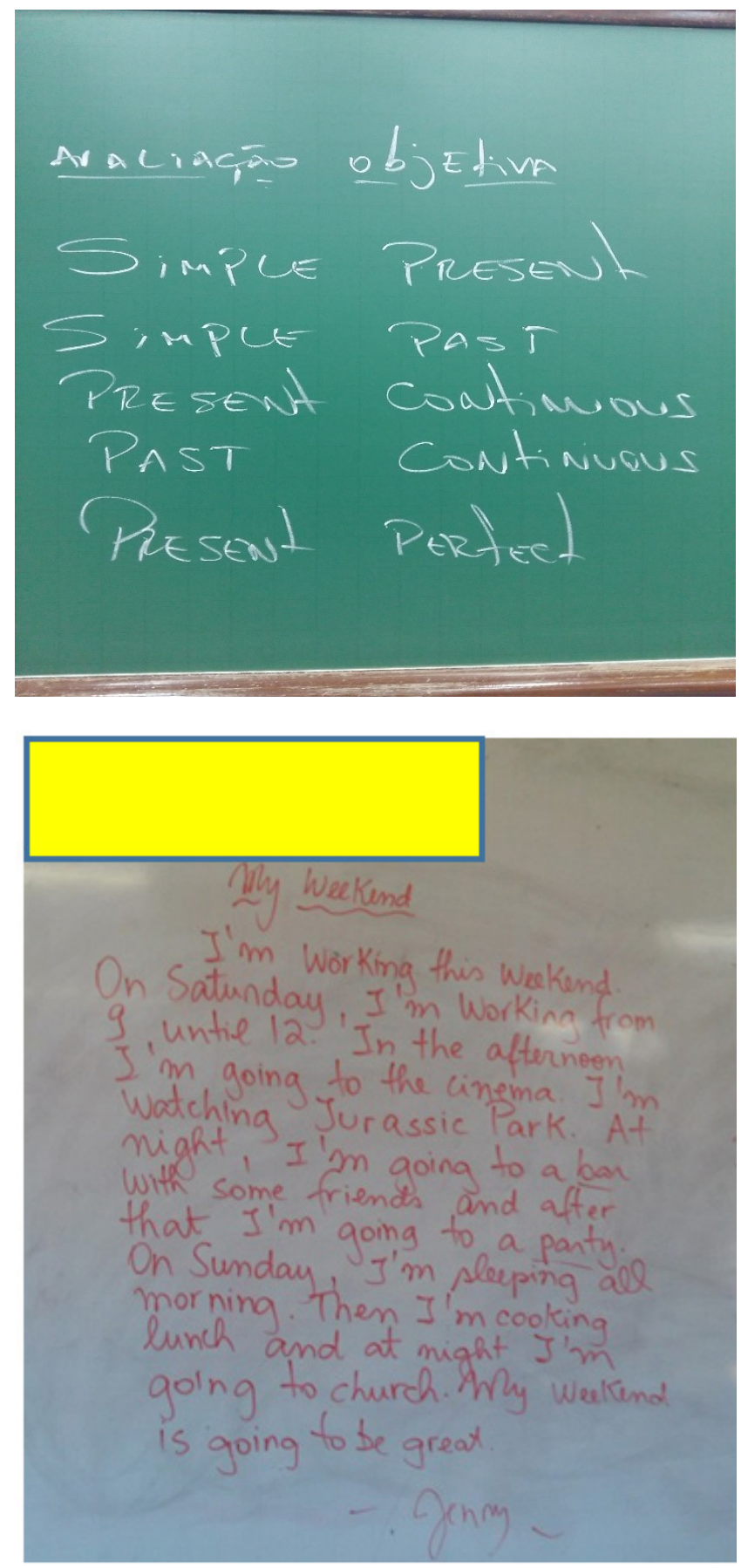

Source: Grant, J. (2016. pp. 95, 90).

Figure 3. Grammatical and communicative approaches in the private and public sectors, Part A and Part B

\footnotetext{
${ }^{6}$ ENEM means National Secondary Level Examination, created in 1998 to assess students performance at the end or after they have concluded the secondary level and as requirement to enter qualify for university scholarship. Link access: portal.mec.gov.br/enem-sp-2094708791

${ }^{7}$ PAS or Programação de Avaliação Seriada is an initiative from University of Brasília (UnB) to assess secondary level students from private and public schools in Brasília to qualify for university scholarship. Further information link: www.cespe.unb.br/PAS/PAS_oque.aspx
} 
Table 3. Profiles identified in the study

\begin{tabular}{|c|c|c|c|c|c|c|}
\hline Oral Profiles & \multicolumn{3}{|c|}{ Public Sector } & $\begin{array}{c}\text { Private } \\
\text { School }\end{array}$ & $\begin{array}{c}\text { Language } \\
\text { School }\end{array}$ \\
\hline & Teacher 1(R7D) & Teacher 2(R8R) & Teacher 3 (R1AV) & Teacher 4(R1EP) & Teacher 4(R1EP) & $\begin{array}{c}\text { Teacher } \\
3(\mathrm{R} 1 \mathrm{AV})\end{array}$ \\
\hline Insufficient & & & & & & \\
\hline Limitrophe & & & & & & \\
\hline Sufficient & & & & & & \\
\hline
\end{tabular}

Source: Grant, J. (2016. Pg. 109) Produced by the author.

Table 3 refers how the observed teachers were ranked, and each profile addresses that: Teacher 1(R7D) was ranked within the insufficient fluency skills type, works in the public sector, tends to adopt the grammatical approach, didn't display evidence of linguistic fluency in English, production of good input necessary to language acquisition needs to be improved, the teacher is on temporary contract for the last eight years, and she stated that in fact her ability is teaching Portuguese, not English; Teacher 2 (R8R) she was ranked within the limitrophe fluency skills type, works in the public sector for the last 25 years, has some oral fluency and tends to adopt the communicative approach, produces some amount of good input, but not sufficient to foster language acquisition; Teacher 3 (R1AV) was ranked within the sufficient fluency skills type, works in the public sector for five years, and in Cooplem Idiomas for six years, where she conducts her classes in the target language, at about $90 \%$ of the time, but in the public sector she uses the target language about $30 \%$ of the time only, and Teacher 4 (R1EP) was the 2nd teacher ranked within the sufficient fluency skills type, he works in the public and private sectors for six years, and in both sectors teaches English in Portuguese. In this particular instance, it is private school policy that English is taught in Portuguese to prepare students to pass the ENEM (examination to access to enter University across the country) and PAS (examination to access to enter University in Brasília de Capital of Brazil). Therefore, this suggests to say that the aim of the school and of the students it is to learn the grammatical rules, and all parts accept that the form can be learnt and taught in the mother tongue, Portuguese.

\section{Conclusions}

We concluded that oral examination is necessary to assess teachers before they are employed by the government to teach languages in the mainstream public schools, therefore the inclusion of EPPLE examination as criteria in the Brazilian concursos públicos could bring more language teaching quality, in view that the examination can certify the oral fluency of the candidate, and teaching language quality can improve significantly in the mainstream public schools in Brazil.

The teaching and learning process of a foreign language is very challenging, thus insufficient oral skills can impact upon low achievement of pupils and poor teaching service delivery, observing that in the public sector students complain about teachers oral skills. Consequently, better government policies need be in place to help teachers to excel in their pedagogical practices and aid students to acquire the foreign language studied. The practice of teaching a foreign language in the mother tongue clearly indicates that its objective can be defeated, and can seriously compromise language acquisition, if interaction between teacher and students are in the mother tongue.

Other conclusion, is that future studies could offer say 'a comparison of non-native teaching practices between Brazil and another country', examining further variables concerning non-native language teachers' needs over all, in the name of all sciences, urging global government to put more emphasis in the language learning-and-teaching, upon the understanding learners do need to have solid knowledge and domain of a second or foreign language studied. Another scope of study would be to explore how non-native English teachers carry out their duties and how public policies or lack of them can impact in the way they teach and the impact in language acquisition.

The paper pointed out that even though a teacher had sufficient fluency he or she still teaches the target language in the mother tongue, which guided us to understand that not only teachers who have low and limitrophe fluency teach a target language in his or her first language. Therefore, two main steps should be looked into carefully: First, language school supervisors need to develop programs to aid teachers with low and or limitrophe fluency to acquire better command of the language taught, and second, develop strategies to help those teachers who have sufficient fluency to teach the target language in the target language.

The study brought the understanding that language teachers - apart from being knowledgeable of the other necessary teaching skills - need to master the language he/she teaches, so their students can have the opportunity to acquire the language they study, not only learn it. Hence, it is important for the Brazilian government to adopt and implement a stricter selection process for language teachers (in the mainstream schools). On the other hand, English language teachers need to be fully aware of the importance to conduct their English classes more thoroughly in the target language. This is to say that sufficient English language fluency is the desirable profile to teach a foreign language.

Finally, we suggest the following: (1) It is imperative that non-native language teachers are assessed before being 
appointed to teach languages; (2) The desirable certification considered to teach is sufficient oral skills, apart from teachers' graduation; (3) The country need to have in place specific language examination to assess non-native language teachers; (4) Government policies need further improvement, such as employment of language supervisors and or coordinators possessing sufficient oral skills to aid language practitioners to promote pupils positive achievement and quality language teaching service delivery, and (5), Quantitative research on non-native language teaching oral skills are needed to validate this study further from the Brasilia scenario.

\section{Acknowledgements}

We are very grateful to Further Education Training Coordination ( Coordenação de Aperfeiçoamento de Pessoal de Nível Superior CAPES) - Ministry of Education, LEA GDF, Cooplem Idiomas, Higher Education Forum, teachers and students for providing the relevant support to carry out and present this research.

\section{REFERENCES}

[1] S. Krashen. S. Principles and Practice in Second Language Acquisition, Oxford: Pergamon Press, 1982.

[2] J. C. P. Almeida Filho. Dimensões Comunicativas no Ensino de Línguas. Campinas, Pontes, 2013.

[3] M. R. Mastrella-de-Andrade. Quem Aprende e Onde se Ensina Inglês? Desafios do Ensino da Competência Linguistico-Comunicativa na Formação Docente. Signum: Linguistica. Londrina, n. 14/1, p. 345 - 362, junho, 2011.

[4] D. A. Consolo. (2005). Classroom Discourse in Language Teaching: a Study of Oral Interaction in EFL Lessons in Brazil. Unpublished PhD thesis. The University of Reading, UK.

[5] P. Freebody. Métodos e Metodologias: Etnografia, Estudo de Caso e Pesquisa-ação Pesquisa Qualitativa em Educação:
Interação e Prática: Editora Sage, 2003.

[6] A. Moura Filho, Pelo Inglês afora: carreira profissional e autonomia na aprendizagem de inglês como língua estrangeira. Originalmente apresentado como Tese de Doutorado em Linguistica Aplicada. Faculdade de Letras, Universidade Federal de Minas Gerais, 2005.

[7] A. Chizzotti. Pesquisa qualitativa em ciências humanas e sociais. Petrópolis, RJ: Vozes, 2006.

[8] C. Laville. J. A. Dionne. Construção do saber: Manual de Metodologia da Pesquisa em Ciências Humanas. Porto Alegre: Armed. Belo Horizonte: Editora da FUMG, 1999.

[9] T. Gimenez. V. L. L. Cristóvão. (Org) Teaching English in context - Contextualizando o ensino de inglês. Londrina: Universidade Estadual de Londrina, 2006. V1. 186p.

[10] J. C. P. Almeida Filho. O professor de língua estrangeira em formação. $3^{a}$. Edição, Campinas, SP Pontes Editores, (2009).

[11] V. L. T. da Silva. Fluência oral: imaginário, construto e realidade num curso de Letras / LE / [s.n.], 2000. Tese (doutorado) - Universidade Estadual de Campinas, Instituto de Estudos da Linguagem.

[12] Consolo, D. A. A Construção de um instrumento de avaliação da proficiência oral do professor de língua estrangeira. Trabalhos em linguística aplicada (UNICAMP), Campinas-SP, v. 43, n.2, p. 265-286, 2004.

[13] J. C. P. Almeida Filho. A Abordagem Orientadora da Ação do Professor: In Almeida Filho, J.C.P. (Org.). Parâmetros Atuais Para o Ensino de Português como Língua Estrangeira. Campinas: Pontes, 1997, p. 12-28.

[14] Consolo, D.A. On student engagement in whole-class oral interaction: From classroom discourse and sociocultural aspects to implications for language learning. Ilha do Desterro. Florianópolis n. 41 9. 041 - 060 Jul - Dez. 2001.

[15] M. Canale. M.Swain Theoretical bases of communicative approaches to second language teaching and testing. In: Applied Linguistics. Chapter 1 From Communicative competence to communicative language pedagogy. Oxford: Oxford University Press, 1983.

[16] Grant, J. Ensinar língua na língua: Perfis de oralidade e uso da língua estrangeira (inglês) na sala de aula.(Dissertation to obtain Master degree in Applied Linguistic at University od Brasília), 2016

\footnotetext{
i Joana Grant is qualified English and Portuguese language teacher, has Master degree in Applied Linguistics, is concerned about the oral skills of non-native language teachers, teaching and learning language quality.

ii Cooplem Idiomas is a nonprofit civil organization, created by public language teachers, on 12/09/1999, by law $5.764,16 / 12 / 1971$ - defined by National Politics of Cooperativism - today has 152 teachers, 13 schools in Brasilia-DF, accommodates approximately 10,000 students each semester, enrolled to learn English, French, Japanese and/or Spanish.
} 